\title{
Land Reclamation Recovery with the Sewage Sludge Use
}

\author{
Cristina Rincon Tamanini ${ }^{1 *}$; Antônio Carlos Vargas Motta ${ }^{1}$; Cleverson Vitório Andreoli ${ }^{2}$ \\ and Benno Henrique Doetzer ${ }^{3}$ \\ ${ }^{1}$ Universidade Federal do Paraná; Curitiba - PR - Brasil. ${ }^{2}$ Departamento de Solos e Engenharia Agrícola; Rua dos \\ Funcionários, 1540; mottaacv@ufpr.br; 80035-050; Curitiba - PR - Brasil. ${ }^{3}$ Companhia de Saneamento do Paraná; \\ Rua Eng ${ }^{a s}$ Rebouças, 1376, 80215-900; Curitiba - PR - Brasil. ${ }^{4}$ EMATER; Rua da Bandeira, 500; Curitiba - PR - \\ Brasil
}

\begin{abstract}
In this work, investigations were carried out with five treatments [control, three doses of lime stabilized sludge (60, 120, $240 \mathrm{Mg} \mathrm{ha}^{-1}$ in dry base) and soil corrective plus mineral fertilizer] to evaluate the immediate recuperation of a borrowed area. The application of stabilized alkaline sewage sludge acted as an acidity corrective, allowed the increase in the organic matter contents (21 to $43.5 \mathrm{~g} \mathrm{dm}^{-3}$ ) and available $P$ (44 to $156 \mathrm{mg} \mathrm{dm}^{-3}$ ). Even with the use of the highest dose, no increase in the concentration of 32 analyzed metals was observed, due to the low concentration of metals in the sludge. The experiment showed that short term restoration of degraded area was possible by using high rates of sewage sludge without metal contamination.
\end{abstract}

Key words: sewage sludge, land reclamation, soil fertility, soil chemistry, degraded area

\section{INTRODUTION}

One of the biggest challenges of the humankind is to conciliate the present development model with the reduction of environment impact and to promote the mitigation of the existing problems. Despite that the impacts originate from the antropic action, the natural resources utilization is necessary, thus the human occupation, the industrial activities and the agricultural systems must be compatible with the ecosystem (FAO 1999; Lima, et al., 2002; Ceccon et al. 2006).

Currently, a very serious problem observed in the cities with a wastewater treatment plant, is related to the destination of the sludge produced in the sewage treatment plants. The suitable final destination of the sludge is fundamental to the treatment facilities to avoid the problems, which come from inadequate alternatives of the final disposal (Sperling and Andreoli, 2001). Many researchers have suggested that the agricultural use of sludge is a reliable way to dispose it (Tsutiya, 2001; Andreoli et al., 2001). The agricultural utilization promotes the use of this residue that is rich in organic matter and nutrients, and can be recycled and returned to the soil as a fertilizer.

The sewage sludge can also be used in the degraded sites with a series of advantages to the establishment and maintenance of the vegetation as the soils from these sites lack in organic matter, nutrients and the biological activity which all can be provided by the sewage sludge. The use of sewage sludge in mitigation and re-vegetation of the degraded soils has been shown to be safe to the

\footnotetext{
* Author for correspondence
} 
humans and to the environment (Tsutiya, 2001; Sopper, 1993; Andreoli et al., 2001). However, the mixture of sewage sludge with other kinds of residues may add toxic elements, undertaking the quality of the material and limiting its agricultural land application (Andreoli et al., 2001).

The objective of this study was to evaluate the potential of high rates application of sewage sludge in the recuperation of degraded site, using the forage crop yield and soil chemical properties as the indicator and compare the sewage sludge with the mineral fertilizer.

\section{MATERIALS AND METHODS}

The experiment was performed in an area of approximately 5 ha used as borrowed area of soil material for the expansion of the International Airport in São José dos Pinhais. The loss of soil surface occurred around 1990, with the complete withdrawal of the topsoil classified as the anthropogenic soil (at the beginning an Alisoil, EMBRAPA, 1999) and geologically originated in Guabirotuba Formation (EMBRAPA, 1984). After 10 years of the soil surface loss, the area did not receive mitigation intervention and was almost bare due to the poor soil condition.

The area was located between the coordinates 22J0684582 and UTM 7174198 and 22J0684636 and UTM 7174195, at an altitude of $908 \mathrm{~m}$. The landscape had a slight undulated to undulated topography of half slope with low possibility of natural regeneration. The region's climate is classified as Cfb (KÖPPEN), subtropical without dry season and annual precipitation between 1,450 and $1,660 \mathrm{~mm}$. In the corresponding period to the development of the activities (January to April of 2003), the average temperature was $20.9^{\circ} \mathrm{C}$ and total precipitation of $481 \mathrm{~mm}$ (SIMEPAR, 2004).

The experiment comprised five treatments, consisting of control (only with liming), three rates of sewage sludge $(57.3,114.5$ and $229.1 \mathrm{Mg}$ $\mathrm{ha}^{-1}$ in dry matter) and one additional treatment where lime and mineral fertilization was applied in order to supply the necessity of the sowing crop. The experimental area of approximately $2000 \mathrm{~m}^{2}$ received an equivalent of $2.6 \mathrm{Mg} \mathrm{ha}^{-1}$ of dolomitic lime filler (percent of effective calcium carbonate of $88 \%$ ) over the whole area to homogenize, facilitate the sowing and stimulate the vegetation growth. Then, it was submitted to sub soiling and harrowing. After the soil descompaction, the plots, measuring $10 \times 8 \mathrm{~m}$, were established, keeping onemeter distance to avoid the contamination during the sewage application.

Around 30 days before the sowing, the plot related to the mineral fertilization, was amended with extra lime application, $\left(15 \mathrm{Mg} \mathrm{ha}{ }^{-1}\right)$ in order to achieve $70 \%$ of base saturation. During the sowing, this treatment received $20 \mathrm{~kg} \mathrm{ha}^{-1} \mathrm{~N}, 110 \mathrm{~kg}$ $\mathrm{ha}^{-1} \mathrm{P}_{2} \mathrm{O}_{5}$, and 80 and $110 \mathrm{~K}_{2} \mathrm{O}^{-1} \mathrm{ha}^{-1}$ as urea $(45 \% \mathrm{~N})$, super phosphate $\left(18 \% \mathrm{P}_{2} \mathrm{O}_{5}\right)$ and potassium chloride $\left(60 \% \mathrm{~K}_{2} \mathrm{O}\right)$, respectively. Sidedress application of $180 \mathrm{~kg} \mathrm{ha}^{-1} \mathrm{~N}$ was applied as urea, according to the recommendations of the Fertilization Committee of Soil from the States of Rio Grande do Sul and Santa Catarina (1989).

The sewage sludge was produced at the Belém sewage treatment plant, located at Curitiba city belonging to SANEPAR Company. The stabilized sewage sludge was produced through the long-term aeration process and was made hygienic by adding 10 to $20 \%$ of its dry weight with $\mathrm{CaO}$ and kept for a period of 70 days. The estimated sewage sludge rates were $0,60,120$ and $240 \mathrm{Mg} \mathrm{ha}^{-1}$ (dry base) and corrected according to the humidity concentration (15.3\%) and global density average of $0.96 \mathrm{~g} \mathrm{~cm}^{-3}$.

The sewage sludge was applied to the soil surface with a specific equipment piece for sewage, followed immediately by the incorporation by sowing. After 31 days, pearl millet (Pennisetum americanum) was sowed in the whole experimental area by homogeneously spreading the seeds and slight incorporation by the disc.

Table 1 - Fertilization parameters of sludge applied to degraded site.

\begin{tabular}{|c|c|c|c|c|c|c|c|c|c|c|}
\hline $\begin{array}{c}\text { Lime stabilized } \\
\text { sludge }\end{array}$ & $\begin{array}{c}\mathrm{N} \\
\text { total }\end{array}$ & $\begin{array}{c}\mathbf{P} * 4 \\
\text { extractable }\end{array}$ & $\begin{array}{c}\mathbf{P} \\
\text { (total) }\end{array}$ & $\begin{array}{c}\mathrm{K} \\
\text { extractable }\end{array}$ & $\mathbf{O M}$ & \multirow{2}{*}{$\begin{array}{c}\mathbf{p H} \\
\mathrm{CaCl}_{2}\end{array}$} & $\mathrm{C} / \mathrm{N}^{* 1}$ & $C^{* 2,4}$ & CEC $* 3,2$ & $\mathbf{U}$ \\
\hline & & & $\mathrm{g} \mathrm{kg}^{-1}$ & & & & $\%$ & $\mathrm{~g} \mathrm{dm}^{-3}$ & $\mathrm{cmol}_{\mathrm{c}} \mathrm{dm}^{-3}$ & $\%$ \\
\hline $10-20 \%$ & 6.1 & $5.0\left(\mathrm{P}_{2} \mathrm{O}_{5}\right)$ & $\begin{array}{c}7.6 \\
\left(\mathrm{P}_{2} \mathrm{O}_{5}\right)\end{array}$ & $0.67\left(\mathrm{~K}_{2} \mathrm{O}\right)$ & 100.7 & 8.1 & 9.2 & 60.6 & 31.9 & 85.9 \\
\hline
\end{tabular}

Note: ${ }^{* 1} \mathrm{C} / \mathrm{N}$ : carbon nitrogen relation, ${ }^{* 2}$ analysis according to defined methodology to soil analysis, ${ }^{* 4}$ neutron citrate of ammonium extraction, ${ }^{* 5}$ organic carbon. 
Table 2 - Chemical elements found on sewage sludge applied to the area.

\begin{tabular}{|c|c|c|c|c|c|c|c|c|c|c|c|c|c|}
\hline Ag & Ba & La & $\mathbf{L i}$ & $\mathrm{Sr}$ & Al & $\mathrm{Ca}$ & $\mathrm{Fe}$ & $\mathbf{K}$ & $\mathbf{M g}$ & Mn & $\mathbf{N a}$ & $\mathbf{P}$ & $\mathbf{T i}$ \\
\hline & \multicolumn{4}{|c|}{$\mathrm{mg} \mathrm{kg}^{-1}$} & \multicolumn{9}{|c|}{$\mathrm{g} \mathrm{kg}^{-1}$} \\
\hline 31 & 415 & 114 & 5.1 & 76 & 28 & 59 & 20 & 2.0 & 37 & 0.6 & 0.4 & 11.0 & 0.2 \\
\hline
\end{tabular}

The sewage sludge was analyzed for $\mathrm{pH}$, total $\mathrm{N}$, organic matter, humidity, $\mathrm{C}: \mathrm{N}$, soluble $\mathrm{P}$ and exchangeable $\mathrm{K}$ through the methodology of Lanarv (1982), $\mathrm{Na}^{+}$according to the methodology defined by EMBRAPA (1997), colorimetric organic carbon as described by Raij and Quaggio, (1983) (Table 1). The total concentration of $\mathrm{Cd}$, $\mathrm{Cu}, \mathrm{Ni}, \mathrm{Zn}, \mathrm{Cr}, \mathrm{Pb}, \mathrm{Hg}, \mathrm{Ag}, \mathrm{Ba}, \mathrm{La}, \mathrm{Li}, \mathrm{Sr}, \mathrm{Al}, \mathrm{Ca}$, $\mathrm{Fe}, \mathrm{Mg}, \mathrm{Mn}, \mathrm{Na}, \mathrm{P}$, and $\mathrm{Ti}$ was determined through multi acid digestion (chloridric, fluoridric and nitric acids, and perchloric drops) and measured by ICP-OES (Optical Emission Spectrometer Inductively Coupled Plasma Spectrometers) adapted by Fernandes et al. (1999) (Table 2; Fig. 1). The soil sample for the chemical analysis was collected from each plot, before the treatment application and after the pearl millet harvesting. One sample for each plot was collected from 20 points at a depth of $0-0.2 \mathrm{~m}$. For the chemical and mineralogical characterization a sample was made composed by all the other collected samples, mixed before the sewage sludge application and one sample composed by each experimental unit after the pearl millet harvest.

The soil samples were analyzed for $\mathrm{pH} \mathrm{CaCl}$ $0.01 \mathrm{M}$, base saturation, exchangeable $\mathrm{Al}^{+3}$, potential acidity to $\mathrm{pH} 7.0\left(\mathrm{H}^{+}+\mathrm{Al}^{+3}\right), \mathrm{Ca}^{+2}, \mathrm{Mg}^{+2}$, $\mathrm{K}^{+}, \mathrm{CEC}$, and $\mathrm{P}$ (soluble) according to EMBRAPA (1997), PAVAN et al. (1992) to K and P (Mehlich $-\mathrm{I}$ ), and organic $\mathrm{C}$ for colorimetric as described as Raij and Quaggio (1983). For K analysis, the extraction methodology through ammonium acetate described by Knudsen et al. (1982) was used. Total contents for $\mathrm{Ba}, \mathrm{Co}, \mathrm{Cr}, \mathrm{Fe}, \mathrm{La}, \mathrm{Li}, \mathrm{Mn}$, $\mathrm{Ni}, \mathrm{Sr}, \mathrm{Ti}, \mathrm{Zr}, \mathrm{V}, \mathrm{Y}, \mathrm{Pb}, \mathrm{B}, \mathrm{Cu}, \mathrm{Ni}, \mathrm{Zn}, \mathrm{Cr}$, and $\mathrm{Hg}$ were determined by multi acid digestion (hydrochloric, fluoric and nitric acids, and percloric drops) and plasma determination ICP OES (Table 3).

$\underline{\text { Table } 3 \text { - Total content and heavy metals and average content related to degraded site fertility. }}$

\begin{tabular}{|c|c|c|c|c|c|c|c|c|c|c|}
\hline$\underset{\mathrm{CaCl}_{2}}{\mathrm{pH}}$ & $\mathrm{Al}^{+3}$ & $\mathbf{H}^{+}+\mathbf{A l}^{+3}$ & $\mathrm{Ca}^{+2}$ & $\mathbf{M g}^{+2}$ & $\mathbf{K}^{+}$ & CEC $^{1}$ & $\mathbf{P}$ & C & $\mathbf{V} * 2$ & clay \\
\hline & \multicolumn{6}{|c|}{$\mathrm{cmol}_{\mathrm{c}} \mathrm{dm}^{-3}$} & $\mathrm{mg} \mathrm{dm}^{-3}$ & $\mathrm{~g} \mathrm{dm}^{-3}$ & $\%$ & $\mathrm{~g} \mathrm{~kg}^{-1}$ \\
\hline 4.10 & 12.4 & 20.4 & 1.12 & 0.84 & 0.13 & 22.47 & 0.30 & 14.5 & 8.9 & 490 \\
\hline Al & $\mathbf{C a}$ & $\mathbf{F e}$ & $\mathbf{K}$ & $\mathrm{Mg}$ & Mn & $\mathbf{P}$ & $\mathbf{T i}$ & $\mathbf{B a}$ & Co & $\mathrm{Cr}$ \\
\hline & & & $\mathrm{kg}^{-1}$ & & & & & \multicolumn{3}{|c|}{$\mathrm{mg} \mathrm{kg}^{-1}$} \\
\hline 60.2 & 0.5 & 45.0 & 3.1 & 3.8 & 0.3 & 0.2 & 1.1 & 105.4 & 10.5 & 84.2 \\
\hline $\mathbf{C u}$ & La & $\mathbf{N i}$ & $\mathbf{L i}$ & $\mathbf{P b}$ & $\mathrm{Sr}$ & V & $\mathbf{Y}$ & Zn & $\mathbf{Z r}$ & \\
\hline \multicolumn{11}{|c|}{$\mathrm{mg} \mathrm{kg}^{-1}$} \\
\hline 31.2 & 24.0 & 26.0 & 16.5 & 80.8 & 20.4 & 59.3 & 4.4 & 61.8 & 19.7 & \\
\hline
\end{tabular}

The delineation was used in randomized blocks, with parcels of $8 \times 10 \mathrm{~m}$, with one meter of distance. The statistical evaluation was made through the analysis of regression and variance (Fisher) and average comparison (Tukey, probability of 5\%).

\section{RESULTS AND DISCUSSION}

\section{Sewage Sludge}

The contents of $\mathrm{Hg}, \mathrm{Cd}, \mathrm{Cr}, \mathrm{Cu}, \mathrm{Ni}, \mathrm{Pb}$, and $\mathrm{Zn}$ were used as the indicators of contamination. The results from the sewage sludge shown in Fig. 1 were compared to the maximum acceptable limits established by state laws (IN-IAP - Proposed Normative Instruction of the Ambient Institute of Paraná, 2000,) and the sewage sludge class B from EPA (Environmental Protection Agency, 1997, CFR part. 503). The comparative results indicate that the concentration values observed on sewage sludge represent $2 ;<15 ; 6.3 ; 13.4 ; 9.3 ; 8.9 ; 21.7 \%$ to $\mathrm{Hg}, \mathrm{Cd}, \mathrm{Cr}, \mathrm{Cu}, \mathrm{Ni}, \mathrm{Pb}$, and $\mathrm{Zn}$ respectively, of the limit established by IN-IAP. With the exception of $\mathrm{Zn}$, the heavy metals level 
represented less than $15 \%$ of the maximum established limit. In relation to EPA, the respective concentrations were $0.6 ; 3.5 ; 2.1 ; 3.1$; $6.7 ; 8.0$ and $7.2 \%$, indicating that the origin of the used material is predominantly domestic with low contamination. Corroborating with our finding, PEGORINI (2002), MIYAZAWA et al. (1996), BARRIQUELO et al. (2003) and WISNIEWSKI et al. (1996) have also found values well below the maximum limit for heavy metal for sewage sludge with predominantly domestic origin.

The amount of heavy metals added by the high doses of sewage sludge did not offer risk of contamination to the soil in the reclamation process studied. The $\mathrm{Cd}$ concentration in the sludge was below the detection limit of $3 \mathrm{mg} \mathrm{kg}^{-1}$ (non-presented data) of the chemical analysis, indicating that the concentration has been below the established limit.

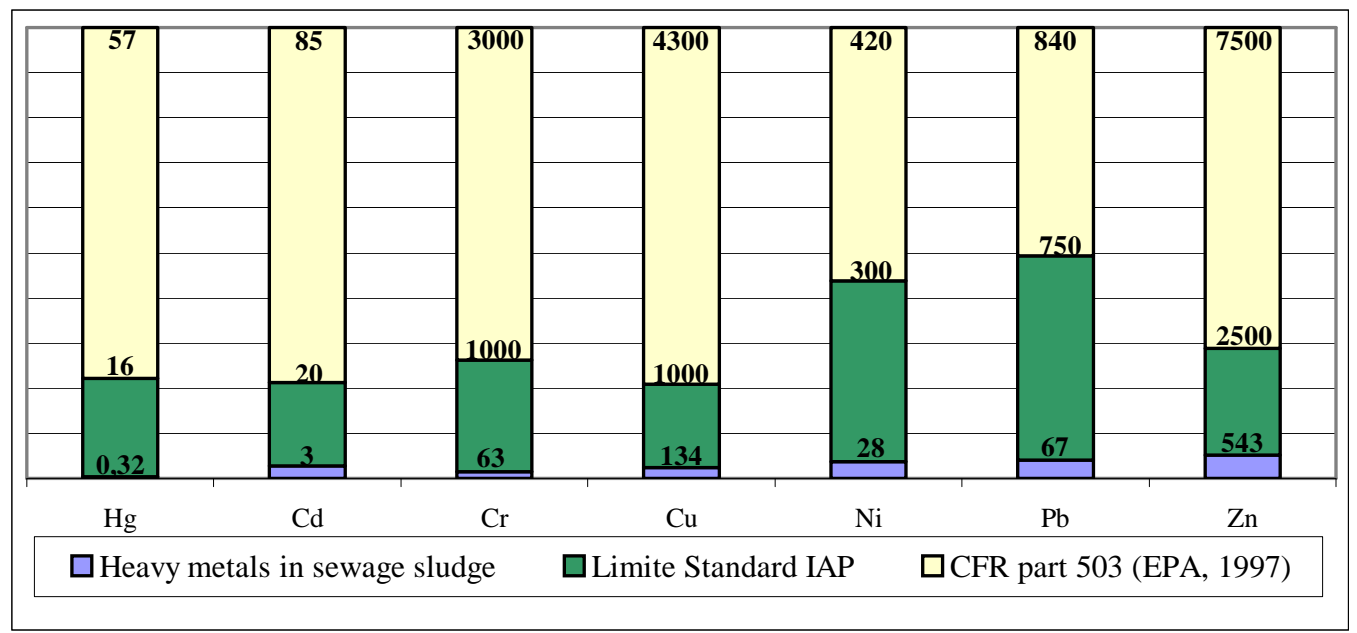

Figure 1 - Concentration of heavy metals $\left(\mathrm{mg} \mathrm{kg}^{-1}\right)$ present in the sewage sludge in comparison with the suggested by in-iap and cfr part 503 (epa, 1997).

\section{Soil}

\section{Carbon and organic matter}

The results indicated that there was a proportional increase between the sewage sludge rates and $\mathrm{C}$ concentrations in the soil (Fig. 2). The treatment which received the highest sewage sludge rate $\left(240 \mathrm{Mg} \mathrm{ha}^{-1}\right)$ presented a $\mathrm{C}$ concentration 2 times bigger than the treatment with mineral fertilization, which had the lowest concentrations as it received only addition of culture residue to this treatment. It was observed, therefore, that the application of organic residues favoured the accumulation of this element in the soil as observed by Nascimento et al. (2004), Barbosa (2000), Berton et al. (1989) and Siengenthaler and Stauffer (1991); the last one working with sewage sludge and dairy manure.

These results have high relevance because the organic matter is one of the most important soil quality indicator (Doran, 1996), and one of the main indicators of the degraded soils mitigation. The results showed that the use of high rates of sewage sludge allowed a fast soil recovering as the $\mathrm{C}$ value obtained after the application was close to the value found in the non-degraded areas in the origin. Almeida (2003) observed a high improvement in the biological activity at the same site after sewage sludge application.

These results confirmed the difficulty of a fast increase of $\mathrm{C}$ through the mineral fertilization and liming as demonstrated by Favaretto (1996), who observed a slow increment of $\mathrm{C}$, limited to the first soil centimeters, indicating that the organic matter recuperation was a slow continuous process and dependent on the tillage system. 


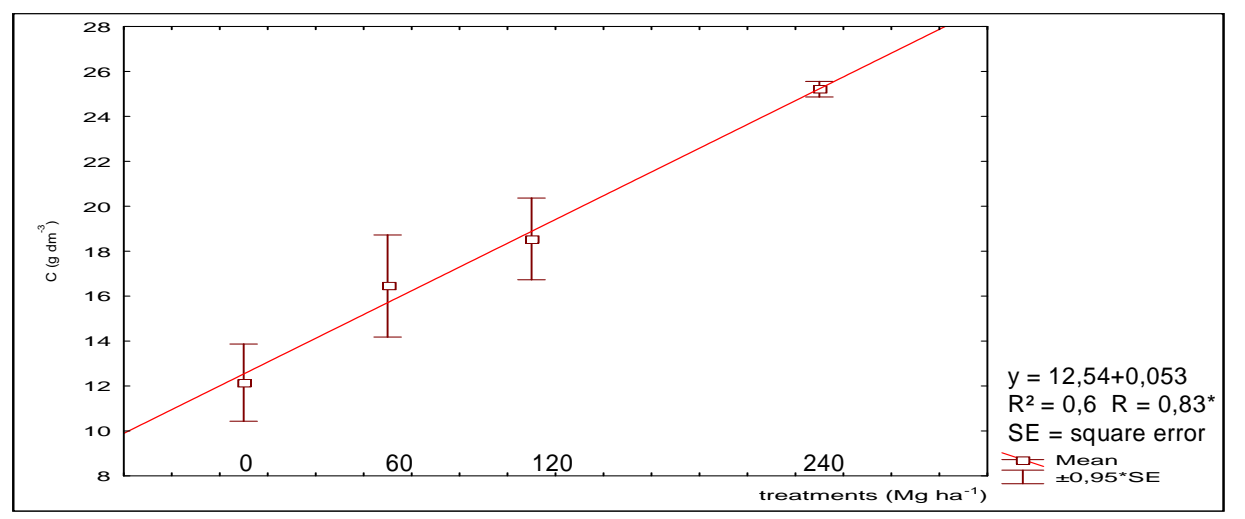

Figure 2 - Level of $\mathrm{C}$ in the soil after high rates of sewage sludge application.

The sewage sludge application promoted a fast mineralization of the organic matter, transforming it into stable composts in the soil maintaining itself for many years Sanches (1981). The high clay content and activity (high specific surface) and the low concentration of the organic matter at the beginning of the experiment probably were soil properties which should contribute to maintaining a large increment of $\mathrm{C}$ in the soil. Castro et al. (2002) observed higher concentrations of $\mathrm{C}$ in locals without soil wastage and fertilization with the use of sewage sludge, where there is a higher amount of organic matter.

\section{Phosphorus}

A linear increase in the availability of $\mathrm{P}$ was obtained according to the dose applied as sewage sludge (Mehlich I), changing from fractions of 1 $\mathrm{mg} \mathrm{P} \mathrm{kg}{ }^{-1}$ soil to more $26 \mathrm{mg} \mathrm{P} \mathrm{dm}^{-3}$ with the usage of $60 \mathrm{Mg} \mathrm{ha}^{-1}$ of sewage sludge (Fig. 3b). This meant that the $\mathrm{P}$ availability passed from a deficient level to very high values with lower sewage sludge rate according to SOIL FERTILITY COMMITTEE of the STATES of RS and SC; (1989). Build up P availability has been shown in different conditions by Nascimento et al. (2004), Berton et al. (1989), Silva et al. (1998) and Wisniewski et al. (1996), even with a rate application lower to the $\mathrm{P}$ added in this study. The high rates of sewage sludge applied will probably have as a result a residual effect for many decades, since McCollum (1991) showed P elevation (in sandy soils with a low buffer capacity) to values between 100 and $120 \mathrm{mg} \mathrm{dm}^{-3}$, allowed the corn production maintenance for 14 years without the addition of $\mathrm{P}$ through fertilizer.
The application of sewage sludge in order to increase the $\mathrm{P}$ in the soil to such high values must be done carefully in the areas susceptible to runoff, because it might arouse water streams contamination, as has been observed in the areas which received large amounts of animal residues for a long period of time (Daniel et al., 1998).

The application equivalent to $1,260 \mathrm{mg} \mathrm{kg}^{-1}$ generated an increase of approximately $156 \mathrm{mg}$ $\mathrm{dm}^{-3}$ (240Mg ha ${ }^{-1}$ of sewage sludge), which meant an increase of approximately $12 \%$ at the available form, indicating a high fixation capacity of this element in the soil. The high amount of 2:1 with hydroxide $\mathrm{Al}$ interlayer in this soil might have large $\mathrm{P}$ potential for specific absorption like as observed for McLauhghlin et al. (1981). Thus, the addition of $1 \mathrm{mg} \mathrm{kg}^{-1}$ of $\mathrm{P}$ through sewage sludge, elevated the available $\mathrm{P}$ in the soil to 0.06 units.

There was a high $\mathrm{P}$ build up, from $200 \mathrm{mg} \mathrm{P} \mathrm{kg}^{-1}$ to more than $1,100 \mathrm{mg} \mathrm{kg}^{-1}$ (Fig. 3a) and like Mehlich $P$ extracted, a linear increment was observed for total $\mathrm{P}$ as result of sewage sludge rates increment. These increases were very expressive since the initial content of near $200 \mathrm{mg} \mathrm{kg}^{-1}$ was compared to the value observed at the Cerrado region, highly weathered soils, known as very poor in $\mathrm{P}$ (Goedert et al., 1986) passing to values higher than $1,000 \mathrm{mg}$ $\mathrm{kg}^{-1}$, which was the content of the rich soils of the cultivated areas from Campos Gerais region (Sá, 1994). Increase in total $P$ contents have also been observed through the long usage of animal residues as it has a permanence of $\mathrm{P}$ in the soil, due to a low mobility (Sharpley et al., 1994). The use of sewage sludge allowed an immediate correction of the $\mathrm{P}$ deficiency, concentrating the stocks in the soil which permit the supply to the plants for a long period of time 


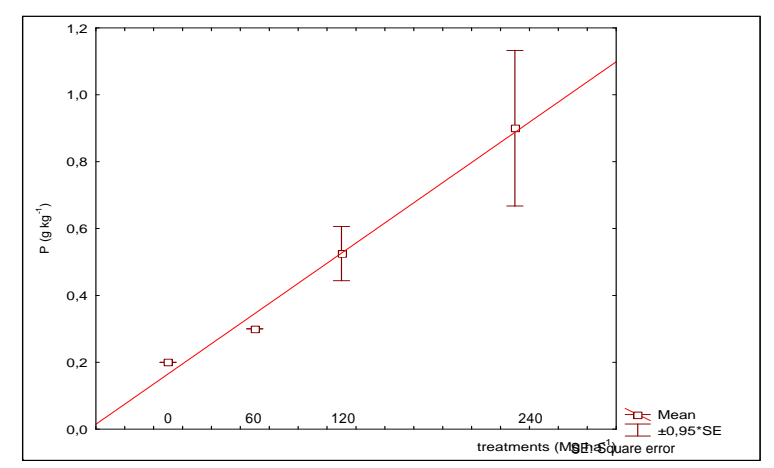

Figure $3 \mathrm{a}-\mathrm{y}=0.003 \mathrm{x}+0.16 \quad \mathrm{R}=0.76^{*} \quad \mathrm{R}^{2}=0.58$.

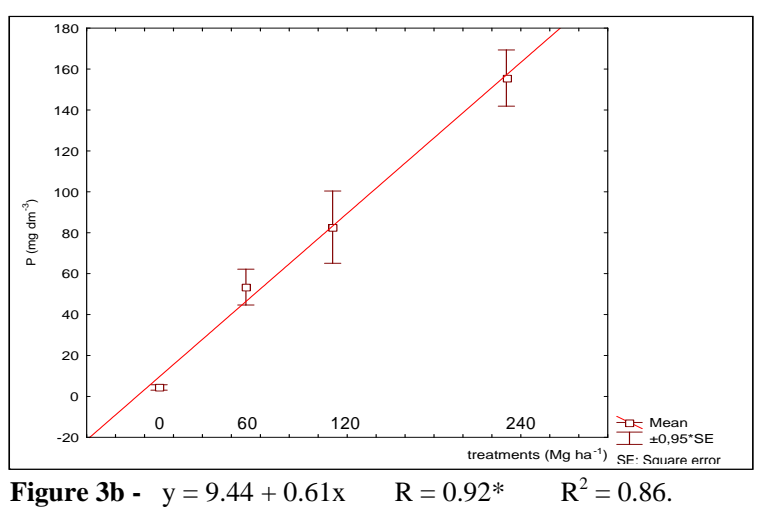

Figure 3a, b - P Levels in the soil after high doses application of sewage sludge.

\section{Potassium}

The difference between the values extracted by the two methods was evident (Fig. 4b,c), due to the high activity clays participation in charge generation. The extraction method with ammonium acetate showed higher extraction capacity compared with Mehlich I. This has been associated with the presence of $\mathrm{NH}_{4}{ }^{+}$, which has approximately the same ionic radium as the $\mathrm{K}^{+}$, being able to substitute it at the sites of high energy (Nemeth, 1982).

Different from $\mathrm{P}$, the $\mathrm{K}$ availability was not affected or decreased at the extracted concentrations through Mehlich I methods and ammonium acetate, respectively. This result was not expected, due to the quantity of $\mathrm{K}$ applied through the sewage sludge which was quite above the usual utilized in the chemical fertilizations. However, no change in the $\mathrm{K}^{+}$concentration through the use of sewage sludge has been observed in many conditions (Silva et al., 1998; Wisniewski et al., 1996) utilizing Mehlich I as an extractor.

A reduction in ammonium acetate extracted $\mathrm{K}^{+}$ could be related to the soil mineral and chemical characteristics, clay presence 2:1 (smectite in most parts, vermiculite and mica) and high concentration of $\mathrm{Al}^{+3}$ (Table 1 and Fig. 7). Probably part of this $\mathrm{Al}^{+3}$ might have come from the partial chlorotization of the high activity clays and could be blocking the internal charge sites of the clays 2:1. The $\mathrm{pH}$ elevation, through the application of sewage sludge, could have caused an $\mathrm{Al}^{+3}$ decrease, with an increase in the capacity of the $\mathrm{K}$ fixation in the soil, causing a reduction in the $\mathrm{K}^{+}$extraction capacity. Nemeth (1982) working with the Brazilian soil, showed that lime application increased the $\mathrm{K}^{+}$fixation in some soils due to the decrease in $\mathrm{Al}$ and $\mathrm{Fe}$ which were blocking the selective sites. The increase of the CEC to pH 7.0 (non-presented data) when sewage sludge was applied gave proof for this hypothesis. However, it was not possible to confirm this fact since CEC increment might also been related to the organic $\mathrm{C}$ enhancement shown before.

Besides the time of collection of clay mineral, the soil samples might, in part, have also affected the results, once these samples were taken at the millet development period and approximate values near $100 \mathrm{~kg}$ of $\mathrm{K}$ (non-presented data) were found at the upground parts. Wastage due to leaching might have had little influence due to the high CEC in the soil and high fixation capacity. Anjos (1999) observed loss because of leaching between 10 and $16 \%$ of the $\mathrm{K}$ applied, in the soil with $6.6 \mathrm{cmol}_{\mathrm{c}}$ $\mathrm{dm}^{-3}$ of CEC after two years.

The total $\mathrm{K}$ content in the soil was reduced at the treatments which received sewage sludge (Fig. 4a). A probable explanation could be the addition of basic components which could be decreasing the acid attack of the total extraction.

Thus, the use of the lime stabilized sewage sludge effects on $\mathrm{K}$ were adverse and could not be taken to other soil conditions of Brazil, because of high activity of clay in high acidity conditions. 


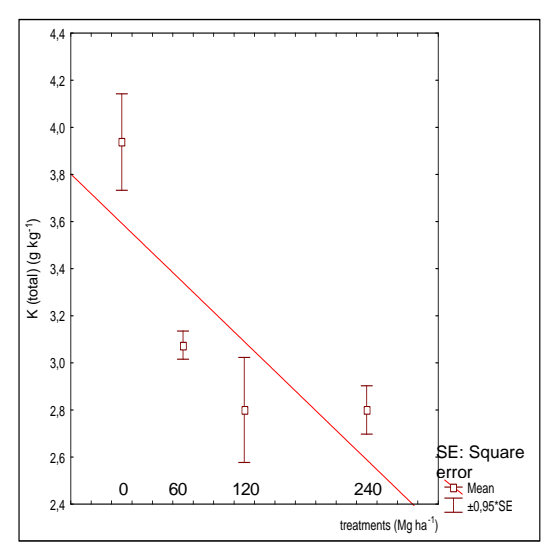

Figure. $4 a-y=-0.004 x+3.58 \quad R=0.67 *$ $\mathrm{R}^{2}=0.45$.

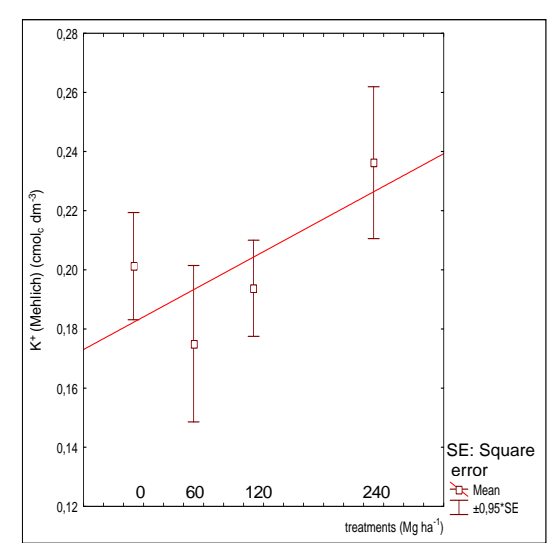

Figure $4 b-y=0.182+0.0002 x \quad R=0.35^{\text {ns }}$ $\mathrm{R}^{2}=0.13$.

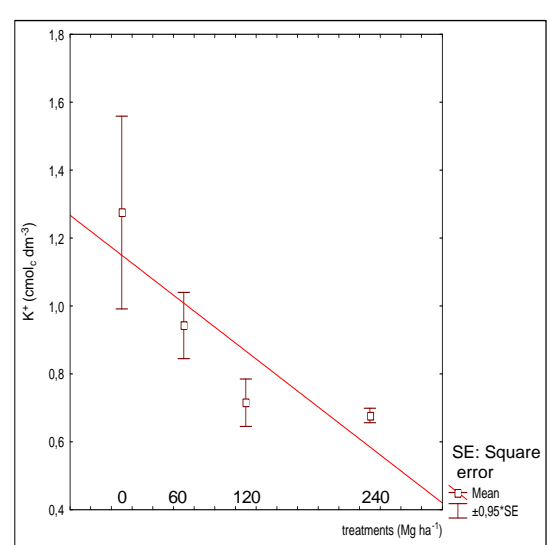

Figure $4 c-y=-0.002 x+1.15 \quad R=0.56^{*}$ $\mathrm{R}^{2}=0.32$.

Figure 4a,b,c - K levels, $\mathrm{K}^{+}$(mehlich) and $\mathrm{K}^{+}$(ammonium acetate) in the soil after high doses of sewage sludge application.

\section{Calcium}

A linear increase between total $\mathrm{Ca}$ and sewage sludge rate was found. The treatment with the highest rate of sewage sludge $\left(240 \mathrm{Mg} \mathrm{ha}^{-1}\right)$ provided more $\mathrm{Ca}$ than the other treatments, practically four times the quantity on the treatment with $60 \mathrm{Mg} \mathrm{ha}^{-1}$ and being around 8.3 fold superior when compared with the control treatment (Fig. 5a).

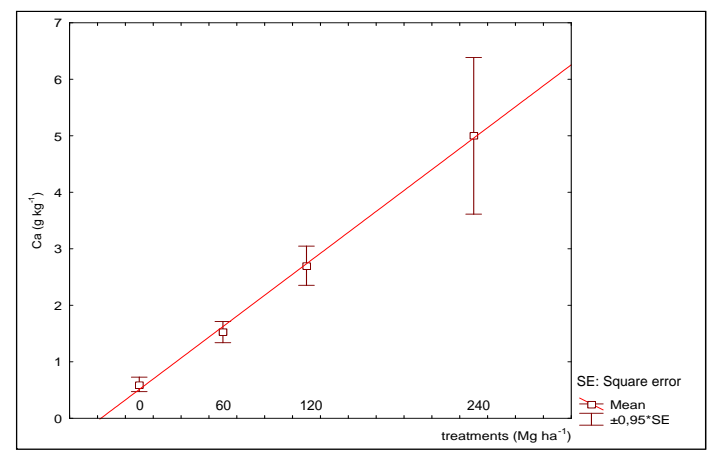

Figure 5a - $y=0.019 x+0.5 \quad R=0.78^{*} \quad R^{2}=0.61$.
An elevation at the exchangeable $\mathrm{Ca}$ concentrations was observed according to applied rate, having the tendency of stabilization at the higher doses with the values around $13 \mathrm{cmol}_{\mathrm{c}} \mathrm{dm}^{-3}$ (Fig. 5b). The results Berton et al. (1989), were similar to those of Silva et al. (1998), Nascimento et al. (2004), Barbosa (2000) and Anjos (1999) who found a $\mathrm{Ca}$ increment when sewage sludge was applied.

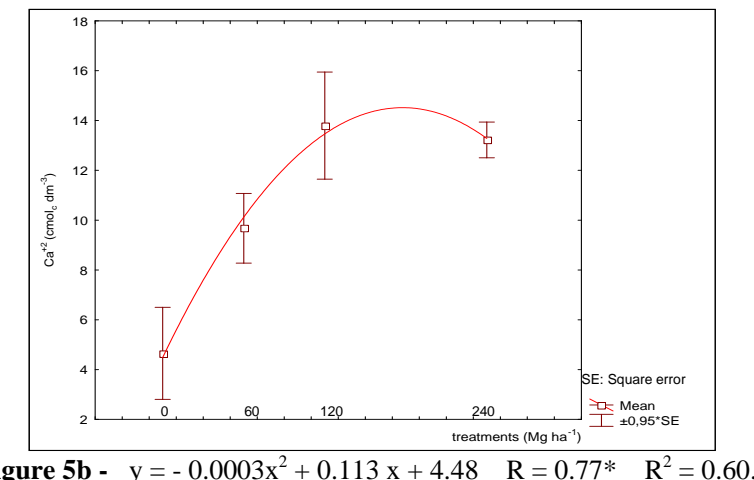

Figure 5a, b - Total and changeable Ca levels in the soil after high doses of sewage sludge application.

The exchangeable concentrations of $\mathrm{Ca}$ were classified as high in all the treatments due to $\mathrm{Ca}$ addition, not only through the sewage sludge, but also through the lime in all the treatments. The total $\mathrm{Ca}$ and exchangeable contents in the soil at the treatment which received the lowest doses of sewage sludge $\left(60 \mathrm{Mg} \mathrm{ha}^{-1}\right)$ was almost twice as bigger as the treatment which received the lime, showing the highest efficiency of the material application at the availability of $\mathrm{Ca}^{+2}$ in the soil related to lime utilization.

The high $\mathrm{Ca}$ availability in the treatments which received the sewage sludge compared to the one with the lime application could be explained by a faster liberation of calcium hydroxide compared to $\mathrm{CaCO}_{3}$ from the lime. Though, the utilized lime could have concentrations of $\mathrm{Ca}$ lower than what was expected, for this reason there was no 
expected increase of total $\mathrm{Ca}$ and the reduction of $\mathrm{Al}^{+3}$ on the treatment.

\section{Magnesium}

For the total $\mathrm{Mg}$, no statistical variation among the treatments was observed, despite the tendency of elevation of its concentrations. The $\mathrm{Mg}$

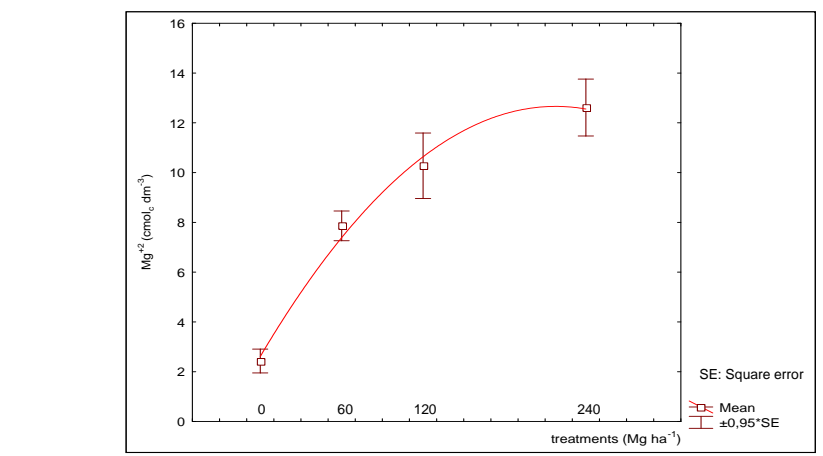

Figure 6a - $y=-0.0002 x^{2}+0.092 x+2.61 \quad \mathrm{R}=0.91 * \mathrm{R}^{2}=0.82$. contribution to the treatment with the mineral fertilization showed a higher concentration when compared to the control, probably because of a high quantity of this element was added to the soil through the liming. However, all the treatments obtained high concentrations of this element (Fig. $6)$.

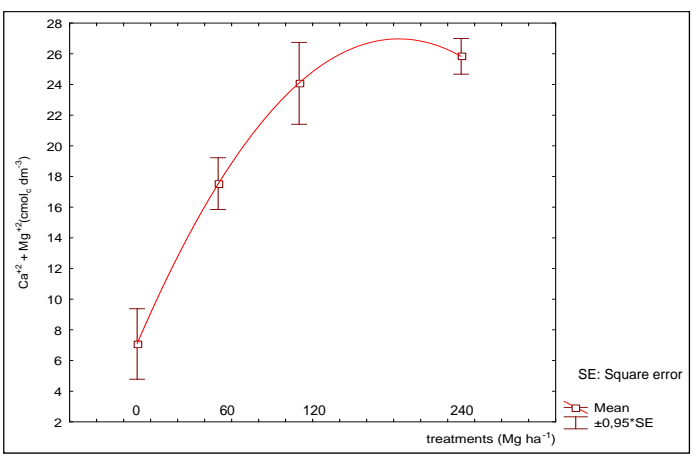

Figure 6b - $y=-0.0005 x^{2}+0.205 x+7.093 \quad R=0.89 * R^{2}=0.80$

Figure 6a, $\mathbf{b}$ - Exchangeable $\mathrm{Mg}^{+2}$ and $\mathrm{Ca}^{+2}+\mathrm{Mg}^{+2}$ concentrations in the soil after application of high doses of sewage sludge.

In disagreement with $\mathrm{Mg}^{+2}$ concentrations, the study made by Anjos (1999) did not show statistical differences in relation to the treatments with the successive applications of the sewage sludge, attributing to the fact that despite the addition of $1,173 \mathrm{~kg}^{\mathrm{ha}^{-1}}$ of $\mathrm{Mg}^{+2}$, this concentration was not enough to elevate the concentration of the element. This data contradicted the ones obtained in the studied soil, where high concentration of $\mathrm{Mg}$ and the soil saturation were quickly reached at the doses of 120 and $240 \mathrm{Mg} \mathrm{ha}^{-1}$.

Like exchangeable $\mathrm{Ca}^{++}$and $\mathrm{Mg}^{++}$, the combined value $\left(\mathrm{Ca}^{++}+\mathrm{Mg}^{++}\right)$showed progressive decrease of exchange value with the sewage sludge rate due to the reduction of the reactions in the soil as a result of the $\mathrm{pH}$ elevation (Fig. 6a,b). The control treatment presented $\mathrm{Ca}^{+2}+\mathrm{Mg}^{+2}$ concentrations in the soil, 3.6 times lower than the treatment which received the highest dose of sewage sludge $\left(240 \mathrm{Mg} \mathrm{ha} \mathrm{h}^{-1}\right)$. The soil buffer capacity at $\mathrm{pH}$ around 5 to 6 has also influence on $\mathrm{Mg}$ with a tendency to the stabilization of this element in the soil with higher doses.

Favaretto (1996) also observed better results on $\mathrm{Ca}$ and $\mathrm{Mg}$ concentrations in the treatments which received the sewage sludge in relation to the other treatments, compensating the loss due to upground part export, according to the low uptake of these nutrients by the plants.

A decrease was observed in the $\mathrm{Ca}: \mathrm{Mg}$ ratio with the values near 3 , almost up to 1 in the treatments which received the sewage sludge. This close ratio could generate nutritional imbalance in the cultivated plants since there was no adequate relation between these two elements. At relations near $1, \mathrm{Ca}$ absorption decrease might occur which impaired the vegetation growth. The highest $\mathrm{Mg}$ absorption in relation to $\mathrm{Ca}$ was observed at the pearl millet in the treatments which received sewage sludge (data not presented), though without impairing the vegetation growth.

\section{pH in $\mathrm{CaCl}_{2}$ 0.01m and aluminum}

A linear increment of the soil $\mathrm{pH}$ in relation to the applied rates was observed, reaching values near 5.4 for $120 \mathrm{Mg} \mathrm{ha}^{-1}$ of sewage sludge (Fig. 7a), value usually adopted to the main crops of the region. Thence, higher doses than $120 \mathrm{Mg} \mathrm{ha}^{-1}$ could compromise the future productivity, leading to nutritional imbalance (Andreoli et al., 2001) and micronutrients deficiency as observed by Rodrigues et al. (1999). At $240 \mathrm{Mg} \mathrm{ha}^{-1}$ of sewage sludge, the $\mathrm{pH}$ reached maximum value near the restriction band for the crops development (data not shown). The rate of $120 \mathrm{Mg} \mathrm{ha}^{-1}$ could not be used as reference to the other tropical soils as the 
soil utilized presented high buffer capacity as proved by the value of $20.4 \mathrm{cmol}_{\mathrm{c}} \mathrm{dm}^{-3}$ of $\mathrm{H}^{+}+\mathrm{Al}^{+3}$, which in general represented the double value observed in the tropical soils.

The exchangeable $\mathrm{Al}^{+3}$ showed exponential reductions due to the sewage sludge rate application (Fig. 7b). The $\mathrm{Al}^{+3}$ behaviour was expected as the soil $\mathrm{pH}$ was originally very low and increased with the sewage sludge application. The $\mathrm{Al}^{+3}$ concentration reduction might have resulted yet from the $\mathrm{Al}^{+3}$ complexation, due to the organic matter (Ernani and Gianello, 1993) and sewage sludge (Liu and Hue, 1996; Hue, 1992).

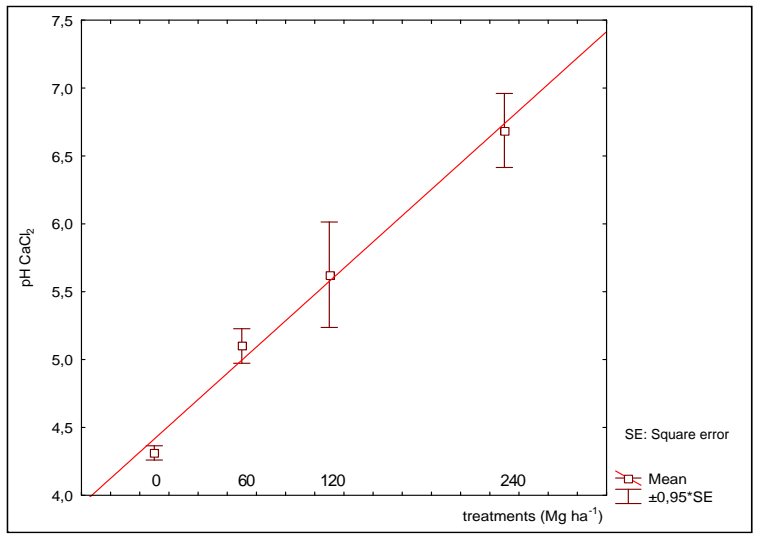

Figure 7a - $\mathrm{pH}=0.0097 \mathrm{x}+4.41 \quad \mathrm{R}=0.88^{*} \quad \mathrm{R}^{2}=0.77$.
When $\mathrm{Al}^{+3}$ is held tightly by the organic matter, the $\mathrm{KCl} 1 \mathrm{~N}$ extraction solution can only displace it partially (Hargrove and Thomas, 1981; Ahmad and Tan, 1986). However, others extraction solutions were able to extract more $\mathrm{Al}^{+3}$, especially from the soil organic matter and in the soil with $\mathrm{pH}$ about 4.8, which was higher limit for $\mathrm{Al}^{+3}$ extraction by $\mathrm{KCl} 1.0 \mathrm{~N}$ (Hargrove and Thomas, 1981; García-Rodeja et al., 2004). Thence, organic matter influenced $\mathrm{Al}^{+3}$ reactions in a wide range of soil $\mathrm{pH}$.

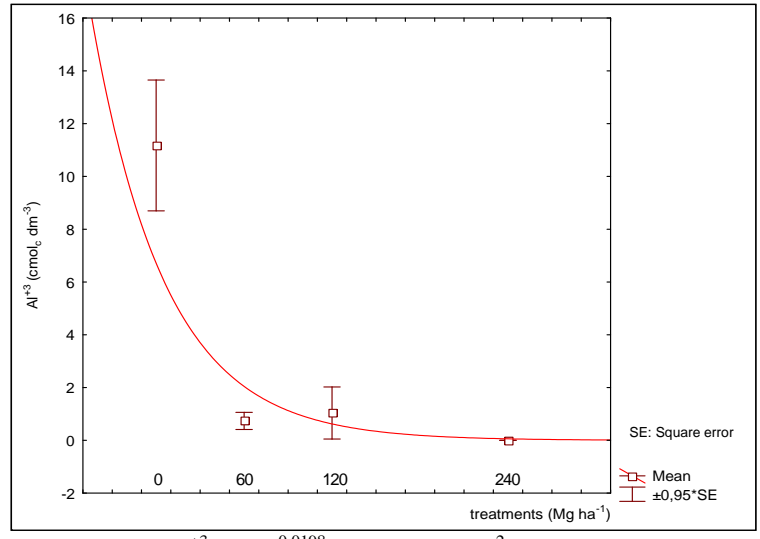

Figure $7 \mathbf{b}-\mathrm{Al}^{+3}=5.5^{-0.0198 x} \quad \mathrm{R}=0.82^{*} \quad \mathrm{R}^{2}=0.68$.

Figure 7a, $\mathbf{b}-\mathrm{pH}$ levels $\mathrm{CaCl}_{2} 0.01 \mathrm{~m}$ and $\mathrm{Al}^{+3}$ in the soil after high application doses of sewage sludge and per millet.

At the treatment which received $120 \mathrm{Mg} \mathrm{ha}^{-1}$ of sewage sludge, an $\mathrm{Al}^{+3}$ concentration of around $1.0 \mathrm{cmol}_{\mathrm{c}} \mathrm{dm}^{-3}$ was observed at a $5.6 \mathrm{pH}$, which was not expected, as theoretically there should not be $\mathrm{Al}$ present in this form at a $\mathrm{pH}$ higher than 4.8. This fact could be explained through a unique repetition of this treatment, which presented this element at the soil profile, elevating this way the treatment average.

Due to high activity of the clay and high $\mathrm{Al}^{+3}$ concentrations, the liming was not enough to neutralize the $\mathrm{Al}^{+3}$ in the treatment which received mineral fertilization. It would also be important to emphasize that the lime quantities added by the sewage sludge to the soil were high enough to achieve neutral $\mathrm{pH}$. However, this soil $\mathrm{pH}$ was not reached, because the soil had a high buffer capacity. The lime stabilized sewage sludge showed to be a very efficient at the activity correction, being able to decrease the land reclamation costs with the use of correctives.

\section{Parameters Related To Heavy Metals}

The usage of high rates of the sewage sludge affected the total concentration of 18 elements (Ba, Co, Cr, Fe, La, Li, Mn, Ni, Sr, Ti, V, Hg, Cu, $\mathrm{B}, \mathrm{Zn}, \mathrm{Zr}, \mathrm{Pb}$ and $\mathrm{Y}$ ) in the soil but significant differences were observed for only $\mathrm{Zn}$, Ti and B. Some elements such as $\mathrm{B}, \mathrm{Fe}$ and $\mathrm{Zr}$ showed a tendency to decrease in the soil after the application of sewage sludge (Table 4), while others presented increase $(\mathrm{Hg}, \mathrm{La}, \mathrm{Cu}$, and $\mathrm{Pb})$. Pegorini (2002), Nascimento et al. (2004), Miyazama et al. (1996) also did not observe any significant increase in the heavy metals concentration after sewage sludge application or urban garbage compost in the soil. Even for the elements with significant differences, the concentrations in the soil were maintained at safe levels according to IN-IAP, Company of Environmental Sanitation Technology (2001) and Environment Protection Agency (1983). 
The application of high doses of the sewage sludge without industrial contaminants to the scoured site indicated no inconvenience in relation to an increase in the levels of heavy metals in the soil (Table 4), with no risk of contamination. It is possible that the high quantity of organic matter at this kind of residue, strongly retained the fractions of these metals, reducing the waste at the environment in the form of leaching and runoff. The application advantage was the reduction of mechanical activities at the site (Sopper, 1993; Miyazawa et al. 1996; Nascimento et al. 2004; Hernandez et al. 1991).

Table 4 - Total and average content of heavy metals at the degraded site after high doses of sewage sludge application.

\begin{tabular}{|c|c|c|c|c|c|c|c|c|c|}
\hline Treatments & $\mathrm{Hg}$ & $\mathbf{B a}$ & Co & $\mathrm{Cr}$ & $\mathbf{C u}$ & La & B & $\mathrm{Fe}$ & Mn \\
\hline & $\mu \mathrm{g} \mathrm{kg}^{-1}$ & \multicolumn{6}{|c|}{$\mathrm{mg} \mathrm{kg}^{-1}$} & \multicolumn{2}{|c|}{$\mathrm{g} \mathrm{kg}^{-1}$} \\
\hline $0 \mathrm{Mg} \mathrm{ha}^{-1}$ & $<50$ & 122.63 & 9.65 & 43.25 & 30.50 & 28.38 & 121.2 & 44.0 & 0.2 \\
\hline Mineral & $<50$ & 123.75 & 11.33 & 42.75 & 29.50 & 28.00 & 174.2 & 43.0 & 0.2 \\
\hline $60 \mathrm{Mg} \mathrm{ha}^{-1}$ & $<50$ & 185.75 & 13.00 & 43.00 & 29.25 & 27.50 & 158.0 & 41.0 & 0.2 \\
\hline $120 \mathrm{Mg} \mathrm{ha}^{-1}$ & 50.5 & 121.75 & 8.65 & 40.25 & 31.50 & 30.00 & 107.0 & 38.5 & 0.2 \\
\hline \multirow[t]{3}{*}{$240 \mathrm{Mg} \mathrm{ha}^{-1}$} & 150.0 & 132.00 & 8.40 & 42.75 & 35.50 & 37.00 & 60.5 & 39.8 & 0.2 \\
\hline & $\mathrm{Ni}$ & $\mathbf{P b}$ & $\mathrm{Sr}$ & V & $\mathbf{Y}$ & $\mathbf{Z r}$ & $\mathbf{L i}$ & Zn & $\mathbf{T i}$ \\
\hline & \multicolumn{9}{|c|}{$\mathrm{mg} \mathrm{kg}^{-1}$} \\
\hline$\overline{0 \mathrm{Mg} \mathrm{ha}^{-1}}$ & 16.13 & 68.88 & 27.75 & 67.25 & 6.86 & 31.50 & 16.63 & $58.88 \mathrm{a}$ & $0.85 \mathrm{ab}$ \\
\hline Mineral & 16.25 & 70.00 & 25.50 & 60.00 & 6.55 & 31.25 & 20.00 & $58.50 \mathrm{a}$ & $0.92 \mathrm{~b}$ \\
\hline $60 \mathrm{Mg} \mathrm{ha}^{-1}$ & 16.25 & 68.75 & 24.00 & 59.75 & 6.25 & 30.75 & 18.25 & $59.75 \mathrm{a}$ & $0.87 \mathrm{ab}$ \\
\hline $120 \mathrm{Mg} \mathrm{ha}^{-1}$ & 15.75 & 71.00 & 23.25 & 57.50 & 6.58 & 22.25 & 17.93 & $67.00 \mathrm{ab}$ & $0.65 a b$ \\
\hline $240 \mathrm{Mg} \mathrm{ha}^{-1}$ & 16.25 & 75.00 & 27.00 & 60.25 & 7.10 & 18.25 & 18.00 & $85.00 \mathrm{~b}$ & $0.55 \mathrm{a}$ \\
\hline
\end{tabular}

${ }^{*}$ The concentrations of $\mathrm{Ag}, \mathrm{Be}, \mathrm{Bi}, \mathrm{Cd}, \mathrm{Sc}, \mathrm{Sn}$ and $\mathrm{W}$ had been below the limit of the laboratory chemical analysis detection.

The concentrations of $\mathrm{Ba}, \mathrm{Pb}, \mathrm{Hg}, \mathrm{Ni}$ and $\mathrm{Zn}$ in the soil (four months after the sewage sludge application) overcame the elements levels, though without reaching the alert levels of a soil considered to be clean. It would be still important to add that even though $\mathrm{Ba}$ was not an element monitored by IN-IAP, it was the element that got closer more proportionally to the alert level, even where there was no sewage sludge addition due to its natural concentration in the studied soil. The applied sewage sludge had around $415 \mathrm{mg} \mathrm{kg}^{-1}$ of $\mathrm{Ba}$ and this material might raise the risks of accumulation of this element in the soil and, consequently, in the food web, as this element could be accumulated by the organisms (Company of Environmental Sanitation Technology, 2001).

It would also be important to mention that the $\mathrm{Hg}$ concentrations in the soil reached values below the detection limit in the laboratory analysis, being detected in two treatments, yet, not in all repetitions. The $\mathrm{Hg}$ level increase in the soil was proportional to the sewage sludge application (Table 4) and could be rapidly absorbed and bio accumulated by the plants and animals at all the trophic levels (Company of Environmental
Sanitation Technology, 2001; Kabata- Pendias and Pendias, 1992).

Although not the part of the heavy metals monitored by the majority of rules and regulations, it would be suitable to say that the $\mathrm{Ti}$ concentration found was inverse to the quantity of the sewage sludge applied (Table 4). The exposition of the soils to the effluents or emission by the industries might result them contaminated by this element; however, the Ti applied through the sewage sludge did not make environmental contamination.

The total concentrations of $\mathrm{Zn}$ presented significant increase between the treatments in function to the applied sewage sludge. The sewage sludge addition contributed to an increase of up to $44.4 \%$ at $\mathrm{Zn}$ concentrations in relation to the control. The addition of each $\mathrm{mg} \mathrm{kg}^{-1}$ of $\mathrm{Zn}$, increased 0.447 units in the soil. The mineral fertilization did not contribute to the addition of this element in the soil as the utilized basic fertilization without this element in the composition.

The total content of $\mathrm{Zn}$ found in the soil varied from 117 to $170 \mathrm{~kg} \mathrm{ha}^{-1}$, therefore, was within the values established by Environmental Protection 
Agency (1983) (Sopper, 1993) and with average contents in the treatments with the sewage sludge variation near to the referred concentration level proposed by CETESB, which have been usually found in the soils from Parana State (Santos Filho, 1983). According to this, even with a significant difference between the treatments, there were no limitations regarding $\mathrm{Zn}$ at very high doses of the sewage sludge in the soil.

\section{ACKNOWLEDGEMENTS}

We thank to the National Council of Scientific an Technological Development, $\mathrm{CNPq}$ for the scholarship to the Sanitation Company of Paraná, SANEPAR through the Research and Development Assessorial (APD); to Brazilian Company of Infrastructure Aero port, INFRAERO and to Pos-graduation course in Soil Science from Federal University of Paraná.

\section{RESUMO}

Obras de infra-estrutura próximas aos grandes centros levam ao surgimento de áreas degradadas por decapamento que podem ser reintegradas a paisagem através dos processos de recuperação com o uso do lodo de esgoto. Estabeleceu-se um experimento com cinco tratamentos [testemunha, três doses de lodo alcalinizado $(60,120,240 \mathrm{Mg}$ $\mathrm{ha}^{-1}$ em base seca) e corretivo mais adubo mineral], para avaliar a recuperação imediata de uma área de empréstimo. A aplicação de lodo de esgoto alcalinizado atuou como corretivo da acidez, proporcionou aumento no teor de matéria orgânica (21 para 43,5 $\left.\mathrm{g} \mathrm{dm}^{-3}\right)$ e P disponível $(4,4$ para $156 \mathrm{mg} \mathrm{dm}^{-3}$ ) e total, se mostrando superior ao mineral mais calagem. Mesmo com uso da maior dose, não foi observado acréscimos nos teores de 32 metais analisados, dado à baixa concentração de metais no lodo. Os resultados obtidos indicam que é possível o uso de doses elevadas de lodo de esgoto na recuperação de áreas degradadas.

\section{REFERENCES}

Ahmad, F. and Tan, K. H. (1986), Effect of lime and organic matter on soybean seedlings grown in aluminum-toxic soil. Science Society of American Journal, 50, 656-661.
Almeida, W. C. (2003), Análise da respiração microbiana e das populações de Acari e Collembola na recuperação de áreas degradadas com a utilização de lodo de esgoto, UFPR, Curitiba, 122p.il. dissertação de mestrado.

Andreoli, C. V., Pegorini, E. S., Fernandes, F. (2001), Disposição do lodo no solo, capítulo 8, In-Andreoli, C. V., Lodo de esgotos: tratamento e disposição final/ C. V. Andreoli, M. von Sperling, F. Fernandes (Princípios do tratamento biológico de águas residuárias; pp. 319-398, Belo Horizonte: Dep. de Engenharia Sanitária e Ambiental, UFMG, SANEPAR, pp. 484.

Anjos, A. R. (1999), Lixiviação de espécies químicas em latossolos sucessivamente tratados com lodo de esgoto e disponibilidade de metais pesados para as plantas de milho - ESALQ. Piracicaba, Tese (Doutorado em Agronomia), pp. 191.

Barbosa, G. M. C. (2000), Avaliação dos efeitos do lodo de esgoto nas propriedades físicas e químicas de um latossolo roxo eutrófico após dois anos de uso contínuo - UEL, Centro de Ciências Agrárias, Londrina, Dissertação de mestrado, pp. 56.

Barriquelo, M. F., Juliatti, M. A., Silva, M. S. et al. (2003), Lead behavior in soil treated with contaminated sewage sludge and cultivated with maize. Braz. arch. biol. technol., dez., 46 (4), 499505.

Berton, R., S.; Camargo, O., A.; Valadares, J., M., A., S. (1989), Absorção de nutrientes pelo milho em resposta à adição de lodo de esgoto a cinco solos paulistas - Revista Brasileira de Ciência do Solo. 13, 187-192.

Castro, L A R; Andreoli, C V; Pegorini, E S; Tamanini, C R; Ferreira, A C. (2002), Efeito do Lodo de Esgoto como Recuperador de Áreas Degradadas com Finalidade Agrícola, In-Anais do V Simpósio Nacional de Recuperação de Áreas Degradadas: Água e Diversidade - A C Davide, S A Botelho e S C S Rosado (coordenadores). SOBRADE, 18 a 22, nov. 2002, Belo Horizonte, MG. 536p., pp. 234-236.

Ceccon, E., H., Pilar and Rincon, E.. (2006), Abiotic factors influencing tropical dry forests regeneration. Braz. arch. biol. Technol, .49(2), 305-312.

Cetesb (2001), Relatório de estabelecimento de valores orientadores para solos e águas subterrâneas no estado de São Paulo - Dorothy C. P. Casarini et al. São Paulo, CETESB, 736p. + ap.:il; $30 \mathrm{~cm}$. (série relatórios ambientais).

Comissão de Fertilidade do Solo, RS/SC. (1989), Recomendação de adubação e calagem para os estados do Rio Grande do Sul e Santa Catarina. Passo Fundo: SBCS/EMBRAPA, 2, 128.

Daniel, T. C.; Sharpley, A. N. and Lemunyon, J. L. (1998), Agricultural phosphorus and eutrophication: a symposium overview - Journal Environmental Quality, 27, 251-257. 
Doran, J. W. and T. B. Parkin. (1996), Defining and assessing soil quality. Doran, J. W. Defining Soil Quality for a Sustainable Environment, SSSA Special Publication Number, Madison, Wisconsin, Soil Science Society of America, Inc., American Society of Agronomy, 35, 3-21.

Embrapa. Centro Nacional de Pesquisa de Solos. (1997), Manual de métodos de análise de solos. Rio de Janeiro, (EMBRAPA-CNPS. Documentos, 01), 2, 212.

Embrapa. Centro Nacional de Pesquisa em Solos (Rio de Janeiro, RJ). (1999), Sistema brasileiro de classificação dos solos - Rio de Janeiro: EMBRAPA Solos, V1 e V2, pp. 412.

Ernani, P. R. and Gianello, C. (1983), Diminuição do Al trocável do solo pela incorporação de esterco bovinos e camas de aviário. R. Bras. Ci. Solo, Campinas, 7, 161-165.

Estados Unidos. Environmental Protection Agency. (1997), Land application of biossolids: process design manual. Cincinnatti.

Fao - Poverty Alleviation and Food Security in Asia: Land Resources. (1999), This preliminary report was prepared by FAO-AGL in reference to FAO Regional Office for Asia and the Pacific, July. RAP Publication 1999/2. Disponível no endereço eletrônico acessado no dia 15 de março de 2004: http://www.fao.org/ag/agl/swlwpnr/reports/v_a/a.htm \#hla.

Favaretto, N. (1996), Efeito de adubações e espécies forrageiras na composição química da planta e palhada e na fertilidade do solo em área degradada pela mineração do xisto - UFPR, Curitiba, Dissertação (Mestrado), 105pp.

Fernandes, F., Lara, A. I., Andreoli, C. V., Pegorini, E. S. (org.) (1999), Normatização para a reciclagem agrícola do lodo de esgoto - In: Reciclagem de lodo de esgotos: transformando problemas em soluções, Andreoli, C. V., Lara, A. I., Fernandes, F. (coord), pp. 263-291.

García-Rodeja, E. G.; Nóvoa, J. C.; Pontevedra, X.; Martínez-Cortizas, A. M.; Buurman, P. (2004), Aluminium fractionation of European volcanic soils by selective dissolution techniques. Catena, 56, 155183.

Goedert, J.W.; Sousa, D.M.G.; Lobato, E. (1986), Fósforo - In: Solos dos cerrados, tecnologias e estratégias de manejo, Wenceslau J. Goedert (editor), EMBRAPA - CPAC, Nobel.

Hargrove, W. L.; Thomas, G. W. (1981), Extraction of aluminum from aluminum-organic matter complexes. Soil Science Society of American Journal. 45, 151153.

Hernandez, T.; Moreno, Juan I.; COSTA, F. (1991), Influence of sewage sludge application on crop yelds and heavy metal availability - Soil Science Plant Nutrition, 37(2), 201-210.
Hue, N. V. (1992), Correcting soil acidity of a highly weathered ultisol with chicken manure and sewage sludge, Commun, Soil Sci. Plant Anal., 23(3/4):241264.

Kabata-Pendias, A.; Pendias, H. (1992), Trace elements in soild and plants - Boca Raton Ann Arbor London, CRC Press. 2, 365.

Knudsen, D.; Peterson, G. A; Pratt, P. F. (1982), Lithium, Sodium and Potassium - AMERICAN SOCIETY of Agronomy, inc.; Soil Science Society of America, inc. - Methods of soils analysis part two, Chemical and microbiological properties - A. L. Page, editor; R. H. Miller, associate editor; D. R. Keeney, ass. Editor; number 9 (part 2) in the series agronomy. MadisonWisconsin USA 1159, 2, 229230.

Lima, J. S.; Santo, A. A. do E, Gomes, S. S.; Aguiar, A. de C.; Salles, P. A.; Carvalho, G. C. (2002), Biossistemas na Avaliação do Efeito de Lodo de esgoto na Recuperação de Áreas Impactadas - Anais do VI Simpósio Ítalo Brasileiro de Engenharia Sanitária e Ambiental, Vitória - ES.

Mccollum, R. E. (1991), Buildup and decline in soil phosphorus: 30-year trends on a typic umprabuult. Agronomy Journal, 83, 77-85.

Mclaughlin, J. R., Ryden, J. C., Syers, J. K. (1981), Sorption of inorganic phosphats by iron and aluminum-containing components. Journal of Soil Science 32 (3), 365-377.

Miyazawa, M.; Kamagawa, M. Y.; Mattos, M. S.; Moraes, S. R.; Parra, M. S. (1996), Lixiviação de metais pesados do lodo de esgoto no solo. Sanare, Curitiba, 5 (5), 63-67.

Nascimento, C. W. A.; Barros, D. A. S.; Melo, E. E. C.; Oliveira, A. B. (2004), Alterações químicas em solos e crescimento de milho e feijoeiro após aplicação de lodo de esgoto - Revista Brasileira de Ciência do Solo, 28, 385-392.

Nemeth, K. (1982), Métodos de analises de potássio do solo e sua interpretação. In Simpósio sobre potássio na agricultura Brasileira, Londrina, Instituto Internacional da Potassa, pp. 77-94.

Pavan, M. A.; Bloch, M. de F.; Zempulski, H. da C.; Miyazawa, M.; Zocaler, D. C. (1992), Manual de análise química de solo e controle de qualidade. Londrina: IAPAR, (IAPAR. Circular, 76), pp. 40

Pegorini, E. S. (2002), Avaliação de impactos ambientais do programa de reciclagem agrícola de lodo de esgoto na região metropolitana de Curitiba UFPR, . il - dissertação de Mestrado, Curitiba, pp. 217.

Proposta de Licenciamento Ambiental da Gestão Agrícola do Lodo (2000), Minuta de norma do IAP.

Raij, B. V.; Quaggio, J. A. (1983), Métodos de análise de solo para fins de fertilidade. Campinas: Instituto Agronômico, (IAC. Boletim Técnico, 81), pp. 31.

Teles, C. R.; Costa, A. N.; Gonçalves, R. F. (1999), Produção de lodo em lagoas de estabilização e o seu 
uso no cultivo de espécies florestais na região sudeste do Brasil , Sanare,. 12 (12), 53-60.

Sá, J. C. de M. (1994), Métodos de preparo e calagem pré-implantação ao plantio direto em um solo dos Campos Gerais, Centro Sul do PR. Variação das frações de fósforo e resposta do milho - 121p.il, dissertação de mestrado.

Sanchez, P. A. (1981), Suelos de los trópicos - San Jose, Costa Rica, IICA, pp. 634.

Santos Filho, A. (1983), inco total em alguns solos do estado do Paraná - Revista do Setor de Ciências Agrárias da UFPR, 5, 3.

Sharpley, A. N et al.. (1994), Managing agricultural phosphorus for protection of surface waters: Issues and options. Journal Environmental Quality 23, 437451.

Siegenthaler, A. F.; Stauffer, W. (1991), Environmental effects of long term slurry and sewage sludge application: reasons and measures - Treatment and use of sewage sludge and liquid agricultural wastes, edited by P. L'Hermite (Commission of European communities, Brussels, Belgium). Elsevier applied science, pp. 82-89.

Silva, F. C.; Boaretto, A. E.; Berton, R. S.; Zotelli, H. B.; Pexe, C. A.; Mendonça, E. (1998), Cana-deaçúcar cultivada em solo adubado com lodo de esgoto: nutrientes, metais pesados e produtividade. Pesquisa Agropecuária Brasileira, 33 (1), 1-8.

Simepar - Instituto de Tecnologia SIMEPAR, Disponível no endereço eletrônico acessado no período de setembro de 2002 a maio de 2004: http://www.simepar.br e informações cedidas mediante a solicitação em maio de 2004.

Sperling, M. Von E Andreoli, C. V. (2001), Introdução, Capítulo 1, In-Andreoli, C. V., Lodo de esgotos: tratamento e disposição final/ Cleverson, V., Andreoli, M. von S., Fernandes, F. Belo Horizonte: Departamento de Engenharia Sanitária e Ambiental, UFMG: Companhia de Saneamento do Paraná, 484p. (Princípios do tratamento biológico de águas residuárias; 6), pp. 1-16.

Sopper, W. E. (1993), Municipal sludge use land reclamation - $1^{\mathrm{a}}$ Ed. Pennsylvania: Ed. Lewis Publishers, 163p.:il.

Tsutiya, M. T. - Alternativas de disposição final de lodo de esgotos. In-Lodo de esgotos na Agricultura Editores Milton Tomoyuki Tsutiya, João Baptista Comparini, Pedro Alem Sobrinho, Ivanildo Hespanhol, Paulo de Campos Torres de Carvalho, Adolpho José de Melo, Marcos Omir Marques (2001), São Paulo, SABESP, 1, 468.

Wisniewski, C.; Motta Neto, J. A. M.; Pereira, A. M.; Radomski, M. I.; Sessegolo, G. C. (1996), Uso do lodo de esgoto da ETE-Belém na recuperação de áreas degradadas por mineração de calcário, Sanare, Curitiba, 5 (5), pp. $76-85$.
Received: May 30, 2005; Revised: July 26, 2007; Accepted: April 11, 2008. 